\title{
Swimming with the tide? Britain and the Maastricht Treaty negotiations on
}

\section{Common Foreign and Security Policy}

\author{
Alasdair Blair \\ Contemporary British History, Vol.12, No.4, 1998, pp.87-102. ISSN: 1361-9462.
}

\section{Final Draft}

Despite the importance of the Treaty on European Union, little attention has been paid to the manner in which the negotiations were conducted or to an analysis of particular topics. This article addresses one particular aspect by focusing on Britain's participation in the Common Foreign and Security Policy negotiations. It emphasises that, notwithstanding London being portrayed as an 'awkward' member of the European Union, it was neither awkward nor isolated in the course of the CFSP negotiations. Moreover, Britain eventually accepted a formula which went further than its pre-negotiating position. An important influence on this outcome was the Foreign and Commonwealth Office's stranglehold on the dossier. Conservative MPs were also generally more concerned about symbolic issues, including Economic and Monetary Union, the Social Chapter and the proposed federal goal. Greater freedom was therefore possible for negotiators within the area of CFSP, where Britain formed an effective alliance with other Member States, most notably Italy.

\section{Introduction}

The December 1991 Maastricht European Council ${ }^{1}$ marked the end of the 1990-91 Intergovernmental Conferences on European Political Union and Economic and Monetary Union, and the beginning of a lengthy process of ratification. These events have encouraged broad analysis of the Treaty on European Union itself and the role played by Member States in its negotiation. ${ }^{2}$ Yet, despite the significance of the talks, little scholarly attention has been paid to analysing individual aspects of the negotiations.

This is true both of what proved to be key subjects such as monetary union and social 
policy, and of less visible issues such as the reform of the European Parliament and creation of a Common Foreign and Security Policy (CFSP). This article addresses one aspect of this oversight by analysing Britain's participation in the CFSP negotiations. A flexible stance within this dossier contrasted the government's negative position on social policy and monetary union, where negotiating tactics were dominated by domestic political concerns. ${ }^{3}$ That these pressures were less evident on CFSP owed much to the Foreign Secretary, Douglas Hurd, a long-standing Europhile, whose influence on foreign and defence policy was not constrained by the Prime Minister, John Major, or the wider Cabinet and Parliamentary Party. ${ }^{4}$ This reflected Hurd's strength within Cabinet, with the authority of the Foreign and Commonwealth Office (FCO) increasing after Major's appointment as Prime Minister. ${ }^{5}$ Also, Conservative MPs were more concerned about contentious issues such as monetary union, social policy and the federal goal. ${ }^{6}$

\section{The Talks Begin}

Just as the changed environment caused by the ending of the Cold War and the collapse of the system of Soviet satellites in 1989-90 helped provide an impetus to further European integration and the development of a European foreign and security policy, so external determinants continued to exercise an influence on policy debates after the IGC negotiations began. This was most markedly evidenced by the Gulf War, the emerging Yugoslav crisis and the prospect of future European Community (EC) enlargement. ${ }^{7}$ These developments, and the fact that Member States directed their attention towards Economic and Monetary Union (EMU) and institutional debates, meant that the CFSP discussions were overshadowed in the early phase of the IGC, thereby limiting progress. 
This was true both for the negotiations under the auspices of the IGC on political union and those within the parameters of the North Atlantic Treaty Organisation (NATO). The latter was more concerned with defence than foreign policy questions. ${ }^{8}$ A further external influence was the United States. Any changes to European security structures, and the pre-established dominance of NATO, clearly impinged on the most important member. The US was particularly concerned that a reduction in Europe's dependence upon it would undermine the rationale for its involvement in the Alliance, and thus accelerate the erosion of domestic support for basing American troops in Europe - a view starkly expressed in the 20 February 1991 'Bartholomew memorandum'. 9

In addition to such external determinants, the CFSP negotiations were characterised by the dominance exerted by France, Germany and Britain. This was primarily the product of both geopolitical and strategic considerations. Any attempt to create a European defence force hung on the participation of Paris and London, the only Member States with both the necessary quantity and quality of military resources. This accordingly gave them greater negotiating leverage. By contrast, Bonn's central status was characterised by both its geographic and historic significance to European security. The predominance of key Member States was also symptomatic of the diplomatic dynamics of IGC negotiations: Article 236 of the Treaty noted that 'common accord' among Member States was necessary for determining 'the amendments to be made to this Treaty'. Thus, Community institutions did not play a significant role. The European Parliament was only peripherally involved, taking no part in the weekly negotiations at official level, and while the Commission was permitted to take part in these talks, its representatives only attended infrequently. ${ }^{10}$ Jacques Delors, the President of the 
Commission, seemingly did not want Commission proposals to be constrained by the formalities of the IGC negotiating group, where texts could be modified by Member States. This pursuit of independence, however, diluted the Commission's influence on EPU. When it did put forward a text in the external relations field, it was not acceptable to anybody, even federalist minded states such as Belgium. ${ }^{11}$

Once the negotiations were underway, the Member States basically divided into two groups: those wanting the Europeans to be able to act alone in security operations, if necessary on a large scale, and those who favoured a more minimalist line, working closely with the US and NATO. These groups divided in turn into two further alliances: those who considered that security co-operation should remain intergovernmental, and those who believed a future European security policy should be integrated into the main EC Treaty and subject to qualified majority voting (QMV) (see Table 1). Predictably, London was in the vanguard of those who insisted that decision-taking should be done by intergovernmental means and that NATO should continue to be the cornerstone of European Security. ${ }^{12}$ Britain was the strongest advocate of a key US role, but this position was shared by several smaller Member States including Denmark, the Netherlands and Portugal. For London, the need for US support was not just based on historic sentiment for the Anglo-American special relationship, but also by the harsh reality of the Gulf War, ${ }^{13}$ which indicated that an integrated, separate, European security and defence identity was unlikely to emerge, ${ }^{14}$ especially as any concept of unity diminished once it became evident sanctions and diplomatic initiatives would not solve the crisis. ${ }^{15}$ A product of the lack of cohesion in the Community was that Britain was one of the few European countries to send a large force to the region, ${ }^{16}$ which 
consequently helped to breathe new life into the Anglo-American special relationship. ${ }^{17}$ The Gulf War therefore reinforced '...the majority of those in British government who felt that there was no need to play around with NATO and establish a separate European defence policy'. ${ }^{18}$

\section{Table 1:}

\section{Member States' Positions on Foreign and Security Policy}

\begin{tabular}{|c|l|c|}
\hline \multirow{2}{*}{ Europeanist } & \multicolumn{1}{|c|}{ Integrationist } & Intergovernmental \\
\cline { 2 - 3 } & $\begin{array}{l}\text { Belgium, Greece, Luxembourg, } \\
\text { Spain, Commis sion, } \\
\text { European Parliament } \\
\text { Germany* } \\
\text { Italy* }\end{array}$ & France \\
\hline Atlanticist & Netherlands & $\begin{array}{c}\text { Denmark, Portugal, Britain } \\
\text { Ireland* }\end{array}$ \\
\hline
\end{tabular}

* Reservations

Note: Germany wanted an independent European foreign and defence policy, but acknowledged NATO's merits. Italy was guarded about the benefits of a European foreign policy which replaced or reduced NATO's role. While Ireland was not a member of NATO due to its position of neutrality, it was against an independent European force, and favoured NATO protection.

This preference by London for an Atlanticist defence identity was demonstrated in two unpublished texts in December 1990 and February 1991. ${ }^{19}$ They stressed that any strengthening of Europe's defence should take place within the NATO framework ${ }^{20}$ and emphasised that the Western European Union (WEU) should be used for co-ordinating operations outside the NATO area, while at the same time transforming it into a link between NATO and the future EU (although not forming part of the Union). ${ }^{21}$ This represented a further development for an alliance formed in 1954 which had played a 
marginal role in the provision of European security throughout the Cold War. Its status as a subordinate relation to NATO was still evident at the time of the IGC, despite having undergone a reactivation in 1987 when it co-ordinated the efforts of European Member States in the protection of oil shipping lanes in the Gulf. British advocacy of the $\mathrm{WEU}^{22}$ was a departure from the line adopted by Margaret Thatcher, who had refused to advocate it as a potential vehicle for the provision of European Security, and represented the new government's desire to be involved in Community policy-making, signifying a more constructive and less awkward engagement. Nevertheless, the new British position was not shared by France and Germany, who advocated, in memoranda of December 1990 and February 1991, the full creation of a European pillar within NATO. $^{23}$ The latter document stressed that the European Council should be responsible for deciding which areas of security policy would be classified as common policy, ${ }^{24}$ and advocated the development of an 'organic' relationship between the WEU and EPU. ${ }^{25}$ It therefore contrasted with London's preference for a simple 'linkage' between the European Council and WEU. ${ }^{26}$

\section{The Institutional Debate}

In the wake of such early broadsides, Member States' attention became increasingly focused on other topics, including institutional questions, which were of particular relevance to CFSP discussions. ${ }^{27}$ Here the Commission, European Parliament and certain countries such as Belgium, Germany and Greece, favoured the integration of CFSP into the Treaty as an individual chapter with its own decision-making principles, resulting in it becoming one of the main branches in the tree-like structure which they 
intended the future EU to have. The Netherlands too shared this desire, despite defending the importance of NATO. By contrast, the 'Greek temple' configuration envisaged three pillars, of which CFSP would be one, the others being, first, continued supranational co-operation in the central Community institutions, and second, a new area of co-operation, Justice and Home Affairs (JHA). London favoured the latter model because CFSP co-operation (like JHA) would remain intergovernmental with no interference from the Commission, Parliament or Court of Justice. Denmark and Portugal shared a similar view, ${ }^{28}$ and this structure was embodied in the Luxembourg Presidency's first draft treaty of 12 April $1991 .^{29}$ It did not, however, resolve all issues, such as the question of the defence dimension, the Commission's role and the use of QMV. ${ }^{30}$ For example, the desire by Belgium, France, Germany and Italy for joint actions to be decided by $\mathrm{QMV}^{31}$ was opposed by Denmark, Ireland, Portugal and Britain. $^{32}$ Such differences continued to haunt the negotiations, although by the time of the June Luxembourg European Council ${ }^{33}$ the majority of Member States accepted the institutional design embodied by the pillar structure. ${ }^{34}$

The limited progress made on CFSP within the first six months of the negotiations pleased London, as did the pillared arrangement agreed at the June Council. In addition, discussions inside NATO resulted in a May agreement on force structure whereby London obtained permanent command of the new Alliance Rapid Reaction Corps. But although this was rightly perceived as a major British success which, in conjunction with the pillar structure, could be presented as a victory in the face of more federalist desires, the commencement of the Netherlands Presidency of the Council of Ministers, in July, spelt both opportunity and frustration for London. Although the Dutch 
did not want to see the US estranged from Europe or NATO damaged, they nonetheless advocated the incorporation of foreign and security issues within the Community framework. ${ }^{35}$ The former position reflected British interests but the latter one contradicted them. It is an indication of the complexity of the talks that, just as The Hague and London agreed on the importance of NATO and disagreed on the institutional dynamics, so Paris and London disagreed on the importance of NATO but agreed that policy should be determined on an intergovernmental basis.

That the Dutch Presidency would challenge the pillared structure was not immediately apparent to either Britain or other Member States. This was the result of the natural cessation of Community activities in the holiday month of August and the general acceptance that the negotiations would follow the route charted by the earlier Luxembourg Presidency. Such expectations proved foolhardy when the Dutch advanced their draft Treaty on 24 September 1991. Abandoning the Luxembourg pillar formula with a unitary structure, ${ }^{36}$ it gave more concrete form to common action and cooperation on CFSP. ${ }^{37}$ This approach, which had been outlined in an earlier text on 13 September, ${ }^{38}$ was criticised by many Member States at an officials meeting on 26 September, particularly France and Britain. ${ }^{39}$ It was therefore inevitable that it would fail at the 30 September Brussels General Affairs Council, ${ }^{40}$ with Belgium the sole supporter. ${ }^{41}$ Agreement was consequently reached that the Luxembourg draft would form the basis of future negotiations, ${ }^{42}$ but another revision of the Dutch text was put forward, which contained certain communitarian features, including a majority voting procedure for foreign policy, in early November to be debated by Foreign Ministers at the Noordwijk 'conclave' on 12-13 November. This still fell short of British objectives, 
Hurd noting that Member States' 'vital interests' '...cannot and should not be overridden by majority voting, ${ }^{43}$ Differences were accordingly not solved at Noordwijk, ${ }^{44}$ after which a sizeable gulf remained between Britain and the more integrationist states on the nature of foreign and defence policy, London insisting upon its right to both take vital decisions independently and decision taking by unanimous vote. ${ }^{45}$

\section{A Very British Coup}

In the midst of these arguments, the most striking and public evidence of British engagement in the CFSP negotiations had taken place on the eve of the Foreign Ministers' meeting at Haarzuilen on 5-6 October, when London and Rome put forward a joint proposal as a basis for Ministerial discussions. ${ }^{46}$ Anglo-Italian co-operation had been set in motion some six months earlier at a lunch meeting in Rome on Easter Monday between Hurd and his Italian counterpart, Gianni De Michelis. ${ }^{47}$ Hurd had good personal relations with De Michelis and a particular fondness for Italy, having worked as a diplomat in Rome between 1960 and 1963. These developments were indicative of the FCO's importance to the CFSP negotiations, producing a text which stated:

Political union implies the gradual elaboration and implementation of a common foreign and security policy and a stronger European defence identity with the longer-term perspective of a common defence policy compatible with the common defence policy we already have with our allies in NATO. ${ }^{48}$

This wording was only agreed after a prolonged debate, particularly with regard to the 'common defence policy', which proved to be a major and conscious British concession. London did, however, consider it important to stipulate that any future 
common defence policy should, from the beginning, be defined as needing to be compatible with NATO's common defence policy. At the same time, other Member States' acceptance that there already existed a common defence policy within NATO (and that any future European policy had to be compatible with it) was perceived as a valuable concession to Britain prior to Maastricht. ${ }^{49}$ For De Michelis, the significance of the text was that:

For the first time, the British are accepting the perspective of a common defence policy. This is the decisive phrase in the text, and it represents a historical turning point for the United Kingdom. It signifies that Major's government has decided to move towards European Union. The main obstacle on the road to Maastricht has been lifted. ${ }^{50}$

Both de Michelis and Hurd were of a high enough standing to enable them to sell the agreement to their respective domestic communities. ${ }^{51}$ The text was accurately perceived as an attempt by both countries to steer the negotiations away from the more maximalist Franco-German position, while countering any future federalist aspirations in this policy arena. ${ }^{52}$ The London-Rome axis was therefore mutually beneficial. For instance, although London considered the February Franco-German proposal on security and defence to be a dangerous and flawed document (on both transatlantic relations and the linkage between NATO and the WEU), there existed an awareness within Whitehall that a sole British text would be unlikely to stop the Franco-German juggernaut. In this context, a partnership with a federalist Member State was a means of adding weight to Britain's concept of a European defence identity that would be firmly attached to NATO. This represented traditional British European diplomacy whereby alliances were sought on individual topics, rather than a significant new venture for 
policy-makers. It consequently did not mean that London regarded Rome as a suitable ally for other negotiating points.

The Anglo-Italian proposal demonstrated a spirit of British engagement with the government prepared to compromise so as to obtain influence within the negotiations. Flexibility was, however, heavily influenced by the lack of backbench scrutiny inside of Westminster. ${ }^{53}$ This contrasted with EMU, where MPs tended to be aware of the government's negotiating position, a factor influenced by opposition to a single currency and desire for an opt-out formula. ${ }^{54}$ Italy too perceived the text as a means of obtaining influence, primarily by ensuring that it was not overshadowed by the Franco-German partnership. (Some Member States considered it had 'broken ranks' and aligned with Britain $\left.^{55}\right)$. At the same time the text provided Rome with an ability to play the role of power broker between the competing European and Atlanticist visions. ${ }^{56}$ The proposal's very importance was emphasised by Delors view that it represented 'a step towards a compromise'. ${ }^{57}$ Its effect was to therefore counter the Franco-German axis in the short term and tilt the negotiations away from the maximalist position.

Any euphoria in London was threatened on 11 October, when France and Germany proposed the creation of a European corps as part of an EC-wide defence organisation. ${ }^{58}$ Differing from the Anglo-Italian initiative, it recommended an organic link between the EC and the WEU. By advocating a WEU rapid reaction force (whereas the former aimed at strengthening NATO), it came as a sudden shock to Britain. ${ }^{59}$ But the setback for London's preference of a NATO orientated ESDI proved to be shortlived, as a result of NATO's new 'Strategic Concept' ratified at the November 1991 Rome Summit. Endorsing the development of European multinational forces '...in the 
context of an emerging European Defence Identity...', it equally enhanced Alliance cohesion and reinforced the transatlantic partnership. ${ }^{60}$ Significantly, it reasserted the primary role of NATO in the realm of defence:

The Alliance is the essential forum for consultation among its members and the venue for agreement on policies bearing on the security and defence commitments of Allies under the Washington Treaty. ${ }^{61}$

Emerging from the NATO quadripartite group, consisting of Britain, France, Germany and the US, the text's true significance lay in France's participation, as she had originally not taken part in the revision of NATO strategy. ${ }^{62}$ Although the majority of NATO communiqués are normally rubber stamped by Heads of State and Government, on this occasion President François Mitterrand was initially not prepared to accept the text. ${ }^{63}$ Indeed, it seemed he might 'reject the whole damn thing because he had not seen the text before the meeting, ${ }^{64}$ Mitterrand's hostility was 'not because he saw it as a serious problem, but because he saw it as symptomatic of the US encroaching on purely European institutions'. ${ }^{65}$ The text's emphasis on the importance of NATO did nevertheless mean that the original Franco-German proposal was no longer a viable option and therefore Britain proceeded to the Maastricht European Council with greater optimism on the CFSP issue.

\section{The Maastricht European Council}

A combination of the multiplicity of topics covered at Maastricht and the priority given to social policy and EMU, led most details of the CFSP settlement to be negotiated by Member States' Political Directors. Agreement was brokered on the second day, ${ }^{66}$ policy having been hammered out on the margins. This was clearly symptomatic of the 
negotiations as a whole, where the CFSP dossier had been frozen out of the debate for months in early 1991. In broad terms, the outcome was a compromise more favourable to the Atlanticist vision of Britain than the integrated approach of France and Germany. Member governments were made the dominant actors in the CFSP field, ${ }^{67}$ with the European Council granted the ability to set general guidelines and the Council of Foreign Ministers to act as the decision-maker. ${ }^{68}$ Internationally, CFSP was to be represented by the Community Presidency, which would have general responsibility for implementing measures under the Council. ${ }^{69}$

Of the WEU-related issues, the main problem concerned the declaration dealing with membership. This was partly because Greece made it clear in the days prior to Maastricht that it would have difficulty adopting the Council's conclusions if it continued to be excluded from the WEU. ${ }^{70}$ The problem was solved at the very last stage by the concept of WEU full members and observers, only members of both the EC and NATO could become full members of the WEU, with other NATO countries (Turkey, Norway and Iceland) being permitted Associate membership. ${ }^{71}$ This created the possibility of Greek membership of the WEU and meant that Turkey (with whom it had a conflict of views over Cyprus) could not become a WEU member until it was granted EC membership (of which Greece was the main opposition). This concept of membership was a concession secured by France and Germany and represented a setback for Britain's approach, whose government did not want to turn non-WEU members, such as Turkey and Norway, into second class citizens in defence questions. ${ }^{72}$ Significantly, however, the concept of Associate membership was linked to a proposal by De Michelis which gave such members 'the possibility of participating fully in the 
activities of WEU', ${ }^{73}$ a guarantee which was clearly helpful to London. In contrast, the main WEU declaration involved no substantial problems because the November NATO Rome Summit had ironed out many differences. ${ }^{74}$

Otherwise, the main question concerned the defence clause of the WEU, with Britain being against the creation of a common defence. To this end, a change was made to an earlier Belgian proposal which suggested that 'the common defence policy should in time lead to a genuine common defence', ${ }^{75}$ so that the eventual wording noted that 'the common foreign and security policy shall include all questions related to the security of the union, including the eventual framing of a common defence policy, which might in time lead to a common defence' ${ }^{76}$ This notion of a common defence was assisted by the earlier Anglo-Italian declaration, although London managed to secure that Union policy would be 'compatible with the common security and defence policy" ${ }^{\text {"7 }}$ established within the NATO framework, which was also a development on the AngloItalian declaration. ${ }^{78}$ The position of NATO was thus safeguarded and a common defence policy put off into the future.

In terms of operational capability, the Maastricht agreement allowed for the establishment of common positions on foreign policy, ${ }^{79}$ which were designed to ensure that co-operation took place between Member States to utilise their combined diplomatic influence. ${ }^{80}$ In pursuing common aims the Treaty provided for joint actions ${ }^{81}$ as a means of implementing objectives, with the General Affairs Council deciding the matters suitable for joint action. ${ }^{82}$ Although the Treaty was based upon unanimous decision-making, certain implementatory measures within the scope of joint actions could be taken by QMV. ${ }^{83}$ The formula 'unanimity for substantive decisions, QMV for 
implementing decisions' had been pushed at Maastricht by Belgium, France, Germany, Italy, Luxembourg and the Netherlands. Britain objected to the use of QMV, pressing for unanimity on all matters, whereas virtually all other Member States wanted the mixed procedure. ${ }^{84}$ The introduction of QMV therefore represented a compromise on the part of Britain, although the government was not unduly concerned. While undesirable, London considered it a manageable and small inroad into policy. ${ }^{85}$ The very limitations placed on QMV reflected the desire of many states for national control over foreign and defence policy, as emphasised by national action being allowed in areas determined for joint action, should 'imperative need' require (although the Council was to be immediately informed of the necessity for such action). ${ }^{86}$

Yet, whatever the current limits, the development of common positions and joint actions suggested Member States would in due course progress from the codification of a common security policy to 'the eventual framing of a common defence policy, which might in time lead to a common defence' ${ }^{87}$ In that respect the WEU was central to the process of establishing a common defence policy. The TEU noted it would be an 'integral part of the development of the European Union', though integral did not imply an intimate, interlocked relationship. The Council could only 'request' the WEU to transmit the defence ramifications of decisions taken by the $\mathrm{EC}^{88}$; it could not instruct the WEU to carry out EC defence decisions. The WEU was thus separated from the EC, though WEU members affirmed their preparedness, 'at the request of the European Union, to elaborate and implement decisions and actions of the Union which have defence implications' ${ }^{89}$ Linkage between the EC, WEU and NATO was underlined by the declaration that the 'WEU will be developed as the defence component of the 
European Union and as the means to strengthen the European pillar of the Atlantic Alliance'. ${ }^{90}$ The dual-sided role of the WEU was further emphasised through the objective '...to build up WEU in stages as the defence component of the European Union', ${ }^{91}$ while 'WEU Member States will intensify co-ordination on Alliance issues...with the aim of introducing joint positions...into the process of consultation in the Alliance' and that 'the Alliance... will remain the essential forum for consultation among its members and the venue for agreement on policies bearing on the security and defence commitments of the Allies under the North Atlantic Treaty'. ${ }^{92}$

\section{Conclusion}

During the CFSP negotiations Member States grappled with two basic type of texts. While some - such as Belgium, Germany and Luxembourg - advocated giving the Union a defence role with QMV decision-making, opposition to this was voiced by the Britain, Denmark and Portugal. Some degree of compromise was therefore vital and was primarily achieved through negotiations at official level among the leading Member States in the Community. London's position was principally influenced by the FCO's experience of Community affairs and Hurd's Europhile outlook. The negotiations demonstrated that Britain was not an isolated partner, as it shared objectives with Denmark, Portugal and to some extent the Netherlands, while the Anglo-Italian declaration was of crucial importance. In pursuing its aims of a CFSP built around intergovernmental co-operation and a WEU which safeguarded NATO's role, the government was not harassed by backbench opinion. There was very little concern within the Conservative Party about the direction of the debate, ${ }^{93}$ and the Prime Minister 
managed the interface between domestic political opinion and the CFSP negotiations effectively. One of the reasons for this was MPs general preoccupation with other IGC issues which they considered to be of greater importance, including social policy and EMU.

The influence of the British government was based on its intrinsic importance to CFSP: any agreement without Britain would have been virtually worthless. For London, the negotiations largely represented a success because the institutional distinction was maintained through the pillared structure and the special relationship between Western Europe and North America remained a key element of the European identity. Britain obtained agreement that the WEU would take account of NATO's decisions as well as those of the CFSP, and even WEU decisions on issues outside the NATO area would be taken in close co-operation with other Allies. In comparison, many of the key points of the Franco-German texts were not adopted. These included the creation of a European security and defence academy, the immediate establishment of a common defence policy and the setting of a timetable for a common defence. But some issues were left unresolved and the possibility was left open for a review of CFSP (and the whole Maastricht Treaty) in future. ${ }^{94}$ This prospect appeased France which had been unhappy at the 1991 outcome. As with so many issues in Europe, Britain had won a strategic battle in the CFSP debate, therefore, but it had not won the war. Yet this point was largely lost on British ministers who tended not to see the long-term implications of the agreement, which itself represented a significant retreat from London's pre-IGC position. 
I am extremely grateful to the numerous UK government officials who provided many helpful insights on the CFSP negotiations, Professor John Young and Dr Philip Lynch of the Politics Department at Leicester University and two anonymous referees.

1. 'Conclusions of the Presidency, Maastricht European Council, 10-11 December 1991', Bull. $E C$, Vol.24, Issue 12, points 1.1-1.19.

2. F. Laursen and S. Vanhoonacker (eds.), The Intergovernmental Conference on Political Union, (Dordrecht: Martinus Nijhoff, 1992); J. Cloos et al, Le Traité de Maastricht, (Bruxelles: Établissements Émile Bruylant, 1993); and P. Schoutheete, 'Réflexions sur le Traité de Maastricht', Articles de droit de Louvain, Vol.LIII, No.1, 1993, pp.73-90.

3. S. Bulmer, 'Domestic Politics and European Community Policy-Making', Journal of Common Market Studies, Vol.21, No.4, June 1983, pp.349-363, and S. Bulmer, 'Britain and European Integration', in S. George (ed.) Britain and the European Community, (Oxford: Clarendon, 1992), pp.1-29.

4. A. Blair, 'UK policy co-ordination during the 1990-91 Intergovernmental Conference', Diplomacy and Statecraft, Vol.9, No.2, July 1998, pp.159-182.

5. J. Dickie, Inside the Foreign Office (London: Chapmans, 1992), pp.286-7.

6. See views expressed by Gerald Kauffman c.1021-1030. House of Commons Official Report, Vol.193, 26 June 1991.

7. Of the four immediately likely applicants, Austria, Finland and Sweden were neutral and opposed to joining military alliances. In comparison, while Norway was a NATO member, it was the least likely to accede. For France, this was an added reason for pressing ahead on defence as far as possible to ensure that a defence role for the Community would be acquis before enlargement took place. But for Britain, the very prospect of enlargement was a further reason why the WEU should not become a creature of the EC. It considered the WEU could not be subject to the direction of the Council (or European Council) of the EC when the latter contained not just one avowedly neutral state (Ireland), but four.

8. Defence questions were in light of pressures to reduce defence expenditures within Member States, a withdrawal of forces from Germany and a desire to establish agreement on NATO's new objectives. London and Washington were particularly keen to reach agreement on the last point.

9. The memorandum stressed that the US would not countenance European Member States forming a caucus in NATO which could result in it, and other non-WEU members, being presented with a pre-determined stance. Second, the US was concerned as to what European defence would consist of. NATO had developed a largely US capability, though working through NATO in terms of logistics, communication, transportation and intelligence. Within this area, the concern was that if the Community developed an independent decision-making authority which would activate European (but not NATO) forces in some crises, then the US could be dragged in to conflicts. Finally, Washington was anxious that the development of an independent force would result in a parallel defence framework increasing costs when electorates were demanding expenditure cuts.

10. Cloos, Le Traité de Maastricht, op cit., p.275.

11. 'Political Union: Commission Proposals at the IGC regarding 'Common External Policy', Europe Documents, No.1697/98, 7 March 1991.

12. D. Hurd, Europe Renewed, (London: FCO Verbatim Service, 19 February 1991).

13. N. Gnesotto and J. Roper (eds.), Western Europe and the Gulf (Paris: Institute for Security Studies of the Western European Union, 1992), and United Kingdom, Statement on the Defence Estimates. Britian's Defence for the 90s. Cm.1559-I, Vol.1, ( London: HMSO, 1991), pp.7-28, paras 101-251.

14. Policy had been influenced by the response of other Member States, while the issue of future co-operation was dented by Belgium's refusal to supply Britain with ammunition.

15. Paris meeting of WEU Foreign and Defence Ministers on 21 August 1990. The Guardian, 21 August 1990, p.15. Mitterrand failed to tell Major about the Gulf peace plan that France was prepared to launch in mid-January 1991. See C. Grant, Delors, (London: Nicholas Brealey Publishing, 1994). p.185.

16. The Washington Post, 19 January 1991, p.23. 
17. The Economist, 1 September 1990, pp.23-24.

18. Author's interview: former FCO official.

19. United Kingdom, Defence and Security in Europe, Non-Paper circulated by Britain, 15 December 1990 (unpublished), and United Kingdom, Draft Treaty Provisions on CFSP, 26 February 1991 (unpublished).

20. They also noted that NATO's remit should be widened to cover transatlantic political consultations and relationships with Eastern European countries.

21. The December 1990 British 'non-paper' on CFSP spoke of the WEU forming a 'link' between NATO and the EC, although this was noted under a subject heading of the 'W EU as a bridge between the Alliance and the Twelve'. United Kingdom, Defence and Security in Europe, paras 12-15. The development of the WEU as a 'bridge' between NATO and the EC was noted by Hurd at a press conference on 4 February 1991. Agence Europe, No.5425, 6 February 1991, p.6. Also see D. Hurd, House of Commons Official Report, Vol.193, 26 June 1991, c.1014.

22. A reason why Britain favoured the WEU's development was a belief that it would be more palatable to Parliamentarians as London had been instrumental in its creation in 1954.

23. It should be noted that despite the appearance of a solid Franco-German axis, the latter shared both the Atlanticist position of Britain and the pro-European attitude of France.

24. Agence Europe, No.5424, 4-5 February 1991, pp.3-4.

25. 'Franco-German Proposals at the Intergovernmental Conference on Political Union. Security policy co-operation in the framework of the common foreign and security policy of political union', 4 February. Europe Documents, 15 February 1991, No.1690.

26. See D. Hurd, Europe Renewed, op cit.

27. Agence Europe, No.5420, 30 January 1991, p.5.

28. See, for example, Denmark, 'Proposals for a Common Foreign and Security Policy, respectively', Articles C.1, C.3, and Agence Europe, 5 April 1991, p.4.

29. 'Draft Treaty articles with a view to achieving Political Union', Non-Paper of Luxembourg Presidency, 12 April 1991. Europe Documents, 3 May 1991, No.1709/1710.

30. Agence Europe, 15-16 April 1991, No.5472, p.3.

31. Belgium and Italy advocated a general QMV rule, while France and German y argued major decisions should be taken unanimously, with implementation decided by QMV.

32. Author's interview: FCO official.

33. This was despite the summit being engulfed by the Yugoslav crisis. See, for example, J. Santer, 'Statement concerning the European Council meeting in Luxembourg, held on 289/6/1991, and concerning the term in office of the Luxembourg Presidency', 9 July, European Political Co-operation Bulletin, Vol.7, (Luxembourg: Office for Official Publications of the European Community, 1991), pp.338-344.

34. Britain was essentially happy with the pillar construction, as were Denmark, France, Ireland and Portugal. Some Member States, such as Germany and Italy, accepted the text as a temporary compromise - despite preferring a more integrationist Treaty - while Belgium, the Netherlands and the institutional actors were against it.

35. Financial Times, 1 July 1991, p.4. Also see H. van den Broek, 'Statement concerning the programme of the Dutch Presidency to the European Parliament', 9 July, European Political Co-operation Bulletin, Vol.7, (Luxembourg: Office for Official Publications of the European Community, 1991) pp.345-353.

36. 'The Dutch Draft Treaty', Europe Documents, No.1733-1734, 3 October 1991. Also see Agence Europe, No.5564, 11 September 1991, pp.3-4.

37. Agence Europe, No.5574, 25 September 1991, p.3.

38. Agence Europe, No.5562, 7 September 1991, p.3.

39. Financial Times, 28 September 1991 and Cloos, Le Traité de Maastricht, op cit., p.88.

40. Financial Times, 30 September 1991, and The Times, 30 September 1991.

41. Philippe de Schoutheete, Rapport sur l'Union Politique, Unpublished paper presented to the Institute of European Studies (U.L.B) Brussels, 21 February 1992, p.13.

42. Agence Europe, No.5579, 2 October 1991, p.3.

43. D. Hurd, 'Our message for Maastricht', The Daily Telegraph, 12 November, para.6.

44. Agreement was reached at Noordwijk on minor issues, such as parliamentary approval for incoming Commissioners and raising the number of German MEPs to reflect unification. 
45. The Times, 13 November 1991, and Financial Times, 14 November 1991.

46. Agence Europe, No.5581, 4 October 1991, pp.3-4bis.

47. Agence Europe, No.5589, 15 October 1991, p.3. The text was based on a British draft produced by Peter Ricketts and Sir John Goulden.

48. 'Anglo-Italian declaration on European Security and Defence in the Context of the Intergovernmental Conference on Political Union', para 2, 4 October. Europe Documents, 5 October 1991, No.1735.

49. Author's correspondence: FCO official.

50. Quoted in Europe, No.5589, 15 October 1991, p.3.

51. See R. Putnam, 'Diplomacy and domestic politics: The logic of two level games', International Organization, Vol.42, 1988, p.428, and I.W. Zartman and M. Berman, The Practical Negotiator, (New Haven and London: Yale University Press, 1982), p.20

52. The Independent, 4 October 1991.

53. D. Hurd, House of Commons Official Report, Vol.193, 26 June, c.1019. In the June debate MPs were primarily concerned with the vocation federale and EMU opt-out. In the 14-15 October debate on Defence, the overwhelming majority of MPs paid no attention to CFSP. William Cash was the only individual to refer to the Anglo-Italian declaration in the debate, the only other mention of the political union IGC being made by John Cartwright. House of Commons Official Report, 14-15 October 1991, Vol.196, c. 92 (Cash), and c.215 (Cartwright).

54. Some MoD officials considered acceptance of a 'common defence policy' was an unnecessary concession as the government could no longer adopt a minimalist stance. This was because London occupied a strong position on CFSP due to its cent rality to any future proposals, while domestic political attention was focused on social policy and monetary union. Therefore, the government had greater leeway in the direction it took on CFSP.

55. Financial Times, 10 October 1991.

56. See G. Bonvicini, 'Regional reassertion', in Christopher Hill (ed.), The Actors in Europe's Foreign Policy, (London: Routledge, 1996), p.97.

57. Agence Europe, No.5583, 7-8 October 1991, p.3

58. 'Franco-German Initiative on Foreign, Security, and Defence Policy', point 2, para 1, 11 October. Europe Documents, 18 October 1991, No.1738.

59. Author's interview: FCO official.

60. 'The Alliance's New Strategic Concept'. Agreed by the Heads of State and Government participating in the meeting of the North Atlantic Council in Rome on 7-8 November 1991, paras 52 and 54. Europe Documents, 9 November 1991, No.1742. Also see John Major, ‘ NATO Summit', House of Commons Official Report, Vol.198, c.904.

61. 'The Alliance's New Strategic Concept', para 22.

62. The Economist, 30 March 1991, p.48. For Britain's view on the review of NATO strategy see Statement on the Defence Estimates, pp.29-31, paras.306-310.

63. Author's interviews: former US State Department and FCO officials.

64. Author's interview: former FCO official.

65. Author's interview: former US State Department official.

66. Financial Times, 11 December 1991.

67. The Commission was provided with a right to be 'fully associated' with the work carried out in the CFSP field. Treaty on European Union, Article J.9. In addition, the views of the EP were to be '...duly taken into consideration,' though it was not granted a formal decision-making role on specific matters. Treaty on European Union, Article J.7.

68. Treaty on European Union, Article J.3.1.

69. Ibid., Articles J.5.1 and J.5.2.

70. Agence Europe, No.5622, 4 December 1991, p.5.

71. Ireland and Denmark's desire not to become full WEU members, combined with the issue of NATO membership, meant the status of observers fell on conditions which had to be agreed in accordance with Article 12 of the modified Brussels Treaty

72. Author's correspondence: FCO official.

73. Treaty on European Union, declaration on Western European Union, II. 
74. Part of paragraph 6 of the Rome declaration was transferred directly into section B of the first WEU declaration.

75. Agence Europe, No.5626, 9-10 December 1991, p.4.

76. Treaty on European Union, Article J.4.1.

77. Ibid., Article J.4.

78. 'Anglo-Italian declaration on European Security and Defence in the Context of the Intergovernmental Conference on Political Union', para 2.

79. Treaty on European Union, Article J.2.2, para. 1.

80. Ibid., Articles J.1.3 first indent, and J.2.1. While the agreement noted that Member States would ensure '...that their national policies conform to the common positions' (Article J.2.2), and be upheld internationally (Article J.2.3), the CFSP Title is, by virtue of Article L, excluded from the jurisdiction of the Court of Justice. The agreement did not, however, provide for a mechanism which could be used against a defaulting Member State.

81. Treaty on European Union, Article J.3.

82. Ibid., Article J.3.1. Member States left the question of which issues could be considered for joint action at Maastricht until the June 1992 Lisbon European Council. This was caused by the lack of time.

83. Treaty on European Union, Article J.3.2.

84. Author's interview: former European Secretariat official.

85. It copied a provision out of the environment article (130s, second sentence) which had been introduced in the SEA, but which was itself superseded by the Maastricht Treaty. Nothing had ever been done in that direction under the environment article, so British policy-makers did not think that it was very serious in the CFSP context. Author's correspondence: former European Secretariat official.

86. Treaty on European Union, J.3.6.

87. Treaty on European Union, Article J.4.1.

88. Ibid., Article J.4.2.

89. Ibid., declaration on Western European Union, I, Paragraph 3.

90. Ibid., Paragraph 2.

91. Ibid., Paragraph 3.

92. Ibid., Paragraph 4.

93. At the Conservative Party annual conference in Blackpool no debate was concerned with CFSP is sues. Financial Times, 8 October 1991, p.14 and 11 October 1991, pp.10 and 11.

94. Treaty on European Union, Article J.4.6. 